(C) 1981. The Genetical Society of Great Britain

\title{
HETEROZYGOSITY ESTIMATES IN THE GRASSHOPPER CHORTHIPPUS BRUNNEUS (THUNBERG)
}

\author{
PETER GILL \\ Dept. of Genetics, University of Nottingham, Nottingham NG7 2RD
}

Received 3.xi.80

\section{INTRODUCTION}

Chorthippus brunneus is one of the commonest British grasshoppers. It lives in a wide range of habitats, probably surviving in a greater variety than any other British species of grasshopper. C. brunneus is often found existing sympatrically with other species e.g., $C$. parallelus, $C$. albomarginatus, Myrmeleotettix maculatus and Omocestus viridulus. Little is known of the population biology of this grasshopper, despite it being common, easy to keep and breed in the laboratory (Kelly-Stebbings and Hewitt, 1972). In this paper, mean heterozygosities in different areas are examined.

\section{MATERIALS AND METHODS}

\section{(i) Sampling}

Adult $C$. brunneus were collected in August-October 1978 and 1979 from 4 main collecting areas: Nottinghamshire (14 sites): inland samples from the Essex area, including one sample from Kent (10 sites; exclusively coastal sites from Essex ( 8 sites); Dovedale in Derbyshire (10 sites). At each site the commonest plants and grass species were noted. The mean sample size was $60 \cdot 4 \pm 31 \cdot 7$ (S.D.).

\section{(ii) Electrophoretic method}

Grasshoppers were frozen in liquid nitrogen before storage at $-80^{\circ} \mathrm{C}$ and analyses were carried out within 9 months. Eviscerated thoracic tissue was homogenised in $0.3 \mathrm{ml}$ of dithiothreitol $(2 \mathrm{mg} / \mathrm{ml})$ and centrifuged at 3000 r.p.m. in a M.S.E. bench centrifuge for 10 minutes. The supernatant was removed immediately for electrophoresis. The remaining supernatant was stored at $-80^{\circ} \mathrm{C}$ but much activity was lost on subsequent rethawing.

\section{(iii) Recipes for electrophoretic buffers and enzyme stains}

Electrostarch was used throughout this survey. Eleven enzymes were assayed for fifteen loci, although two of these were not used because of poor resolution due to low staining activity. Nomenclature for enzymes follows Harris and Hopkinson (1976). Seven buffer systems were used:

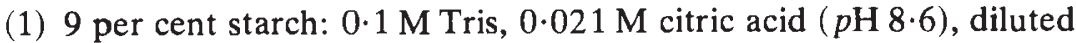
$1: 10$ for the gel buffer. Enzyme: Isocitrate dehydrogenase (IDH).

(2) 9 per cent starch: $0 \cdot 1 \mathrm{M}$ Tris, $0 \cdot 021 \mathrm{M}$ citric acid ( $p \mathrm{H} \mathrm{8.6)} \mathrm{diluted}$ $1: 5$ for the gel buffer. Enzyme:Phosphoglucomutase (PGM). 
(3) 11 per cent starch: $0 \cdot 1 \mathrm{M}$ Tris, $0 \cdot 021 \mathrm{M}$ citric acid adjusted to $\mathrm{pH} 7 \cdot 8$ with hydrochloric acid, diluted $1: 10$ for the gel buffer. Enzymes: Glycerol-3-phosphate dehydrogenase (GPD), Phosphoglucose isomerase (GPI). For GPI, the sample must be diluted $1: 5$ with dithiothreitol as it is a very active enzyme.

(4) 11 per cent starch: $0 \cdot 1 \mathrm{M} \mathrm{NaH}_{2} \mathrm{PO}_{4}$ adjusted to $\mathrm{pH} 7$ with $\mathrm{Na}_{2} \mathrm{HPO}_{4}$ diluted 1:10 for the gel buffer. Enzymes: Glucose-6-phosphate dehydrogenase (GD), Malic enzyme (ME).

(5) 11 per cent starch: $0 \cdot 1 \mathrm{M}$ Tris, $0.021 \mathrm{M}$ citric acid adjusted to $\mathrm{pH} 5$ with hydrochloric acid, diluted 1:10 for the gel buffer. Enzyme: Malate dehydrogenase (MDH).

(6) $0 \cdot 1 \mathrm{MK}_{2} \mathrm{HPO}_{4}$ adjusted to $\mathrm{pH} 7$ with citric acid, diluted $1: 10$ for the gel buffer. Enzyme: Lactate dehydrogenase (LDH).

(7) 11 per cent starch: $0.173 \mathrm{M}$ Tris, $0.017 \mathrm{M}$ boric acid, 0.0025 MEDTA; diluted 1:1 for the gel buffer. Enzymes: Fumarate hydratase (FH), Superoxidase dismutase (SOD), Glutamate oxaloacetate transaminase (GOT), Guanine deaminase (GDA). Recipes for enzyme stains were taken from Harris and Hopkinson (1976).

\section{Results}

\section{(i) Enzyme variation}

Five out of fifteen loci were polymorphic (table 1). The inheritance of isoenzymes was determined by breeding experiments in the laboratory. IDH I was not very active and did not always resolve well; although it was polymorphic and had 2 alleles it was not used in this survey. MDH-MS and MDH-MS' heterozygotes were difficult to distinguish on gels where only one phenotype was present (the mobilities of $S$ and $S^{\prime}$ differed little), hence scores for these two heterozygotes were combined. GPD I was monomorphic. $\mathrm{LDH}, \mathrm{FH}, \mathrm{GD}, \mathrm{ME}, \mathrm{GDA}$ and SOD I produced single anodally migrating bands and GOT produced a single cathodal band. MDH I produced four of five cathodal bands which were faint and difficult to score and were therefore not used in the survey. SOD II produced three anodal bands. Details of locations of collecting sites and gene frequencies are given by Gill (1981).

\section{Discussion}

\section{(i) Analysis of genetic variation}

Frequencies of alleles in populations of $C$. brunneus were broadly similar. IDH II-M, PGM-M and MDH-M were the commonest alleles at polymorphic loci in all populations examined. Gene diversities of populations were analysed according to the methods of Nei (1975) using all detectable loci, including monomorphic ones in the analysis. Estimates of heterozygosity were probably under-estimated because the data for the polymorphic IDH-I locus were not included and esterases were not scored. C. brunneus collected from one area were treated as a single population divided into sub-populations.

The mean heterozygosity $\left(H_{T}\right)$ varied between 0.028 in Essex coast populations and 0.038 in Nottinghamshire populations (table 2). Ferguson 
TABLE 1

\begin{tabular}{|c|c|c|c|c|c|c|c|}
\hline \multicolumn{8}{|c|}{ Enzyme phenotypes } \\
\hline Locus & Structure & No. of alleles & & Observ & ed phe & notypes & \\
\hline IDH II & Dimer & 3 & & $\overline{\bar{E}}$ & & - & \\
\hline IDH I & Dimer & 2 & MM & MF & $\overline{\mathrm{MS}}$ & FS & SS \\
\hline PGM & $?$ & 3 & MM & $\overline{\mathrm{MF}}$ & FF & & \\
\hline MDH II & Dimer & 4 & MM & MF & MF & $\mathrm{FF}$ & MS \\
\hline GPD II & Dimer & 3 & MM & MF & $\overline{\mathrm{MS}^{\prime}}$ & MS & \\
\hline & & & $\mathrm{MF}$ & MM & $\overline{\mathrm{MS}}$ & SS & \\
\hline
\end{tabular}

(1980) quoted an average figure of 10 per cent (the mean for 136 species of animals and plants) whereas the proportion of polymorphic loci ( 33 per cent) was close to the quoted figure of 35 per cent. The gene diversity within populations $\left(H_{S}\right)$ was low $\left(0.037\right.$ in Nottinghamshire). $G_{S T}$ is a measure of the relative magnitude of gene differentiation among sub-populations $\left(G_{S T}=D_{S T} / H_{T}\right)$ and in the present survey showed that only 1.2-2.7 per cent of the total gene diversity $\left(H_{T}\right)$ could be attributed to differences between sub-populations, indicating that over 97 per cent of the total variation therefore exists within sub-populations. $\bar{D} m$ is an estimate of the minimum net codon differences between populations and was a maximum in the Dovedale populations at 0.001 and a minimum in the inland Essex populations $(0 \cdot 00039)$. Nei's (1975) lowest figure for this parameter was 0.003 in man (Yanomama Indians).

The relative heterozygosities of individual polymorphic loci are shown in table 3. IDH II was the most variable locus examined; Nottinghamshire populations had a range of heterozygosities between 0.178 and 0.352 .

TABLE 2

Analysis of gene diversity

\begin{tabular}{lllllc}
\multicolumn{1}{c}{ Area } & \multicolumn{1}{c}{$\boldsymbol{H}_{\boldsymbol{T}}$} & \multicolumn{1}{c}{$\boldsymbol{H}_{\boldsymbol{S}}$} & \multicolumn{1}{c}{$D_{\boldsymbol{S T}}$} & \multicolumn{1}{c}{$G_{\boldsymbol{S T}}$} & $\bar{D}_{m}$ \\
Nottinghamshire & 0.038 & 0.037 & 0.00057 & 0.015 & 0.00062 \\
Essex & 0.03 & 0.029 & 0.00036 & 0.012 & 0.00039 \\
Essex Coast & 0.0284 & 0.0277 & 0.000668 & 0.023 & 0.00076 \\
Dovedale & 0.0336 & 0.033 & 0.00092 & 0.027 & 0.001
\end{tabular}

$H_{T}=$ Gene diversity in the total population

$H_{s}=$ Gene diversity within subpopulations

$D_{S T}=$ Gene diversity between subpopulations

$G_{S T}=$ Relative magnitude of gene differentiation among subpopulations

$\bar{D} m=$ Gene differences between local populations 
TABLE 3

Calculated heterozygosities of polymorphic loci

\begin{tabular}{lllrl}
\multicolumn{1}{c}{ Area } & Locus & Mean $( \pm$ S.E. $)$ & \multicolumn{1}{c}{ Range } & F \\
Nottinghamshire & IDH II & $0.258 \pm 0.021$ & $0.178-0.352$ & 2.769 \\
$\begin{array}{l}\text { Inland Essex } \\
\text { Essex Coast }\end{array}$ & & $0.197 \pm 0.035$ & $0.068-0.478$ & \\
Dovedale & & $0.163 \pm 0.022$ & $0.08-0.235$ & \\
Nottinghamshire & PGM & $0.261 \pm 0.033$ & $0.08-0.376$ & \\
& & $0.138 \pm 0.01$ & $0.052-0.193$ & 4.66 \\
Inland Essex & & $0.144 \pm 0.02$ & $0.063-0.292$ & $(P<0.01)$ \\
Essex Coast & & $0.106 \pm 0.03$ & $0.022-0.243$ & \\
Dovedale & & $0.068 \pm 0.014$ & $0-0.133$ & \\
Nottinghamshire & MDH II & $0.041 \pm 0.008$ & $0-0.114$ & 1.59 \\
Inland Essex & & $0.046 \pm 0.015$ & $0-0.114$ & \\
Essex Coast & & $0.083 \pm 0.03$ & $0.04-0.221$ & \\
Dovedale & & $0.038 \pm 0.01$ & $0-0.085$ & \\
Nottinghamshire & GPD II & $0.051 \pm 0.013$ & $0-0.159$ & 1.7 \\
Inland Essex & & $0.032 \pm 0.007$ & 0.0 .61 & \\
Essex Coast & & $0.025 \pm 0.01$ & $0-0.089$ & \\
Dovedale & & $0.062 \pm 0.013$ & $0-0.153$ &
\end{tabular}

Conversely, MDH-II and GPD-II had very low heterozygosities. Polymorphism at these loci was lacking in several populations.

In order to test whether there were any differences in heterozygosities of individual loci between different areas, analyses of variance were carried out on angularly transformed data (table 3$)$. Only PGM was significant $(P<$ 0.01 ), this was due to low frequencies in the Dovedale populations.

Nei (1975) suggested that low heterozygosities were associated with low population sizes and that vertebrates tended to have lower heterozygosities than invertebrates. The grasshoppers sampled appeared to come from discrete populations. Richards and Waloff (1954) show considerable variation in population size over successive years and fluctuations may be associated with climate. A population of $C$. brunneus studied by Richards and Waloff (1954) was estimated to vary in size between 1100 and 3500 over a period of 5 years. In addition, there was no evidence for large scale movements of grasshoppers. A road or small copse may be sufficient to isolate two populations. It may be expected, therefore, that gene flow between populations is low.

Acknowledgements.-I am grateful to Dr D. T. Parkin for commenting on the manuscript and to S. R. C. for their support.

\section{REFERENCES}

FERGuson, A. 1980, Biochemical Systematics and Evolution. Published by Blackie \& Son Ltd., London.

GILL, P. 1981. Enzyme variation in the grasshopper Chorthippus brunneus (Thunberg). Biol.J. Linn. Soc. (in press).

HARRIS, H., AND HOPKINSON, D. A. 1976. Handbook of Enzyme Electrophoresis in Human Genetics. North-Holland, Amsterdam.

KELLY-STEBBINGS, A. F., AND HEWITT, G. M. 1972. The laboratory breeding of British

Gomphocerine grasshoppers (Acrididae: Orthoptera) Acrida, 1, 232-245.

NEI, M. 1975. Molecular Population Genetics and Evolution. North-Holland, Amsterdam. RICHARDS, O. W.. AND WA LOFF, N. 1954. Studies on the biology and population dynamics of

British grasshoppers. Anti-locust Bulletin 17, 1 182. 